\title{
Pelatihan Microsoft Office 2007 di Desa Sukosari, Kecamatan Dagangan, Kabupaten Madiun
}

\author{
Nanang Junaedi ${ }^{1}$, Candra Budi Susila ${ }^{2}$ \\ ${ }^{\text {I} F a k u l t a s ~ T e k n i k, ~ U n i v e r s i t a s ~ M e r d e k a ~ M a d i u n, ~ J l . S e r a y u ~ N o .79, ~ M a d i u n, ~} 63133$ \\ E-mail: nanang@unmer-madiun.ac.id \\ ${ }^{2}$ Fakultas Teknik, Universitas Merdeka Madiun, Jl.Serayu No.79, Madiun, 63133 \\ E-mail: candra@unmer-madiun.ac.id
}

\begin{abstract}
Information Technology has grown rapidly in Indonesia. Almost all problems can be handled by a computer. For this reason, every level of society must be ready and able to follow along with the development of technology. After the development of information technology, typewriter users moved to the computer. Because of its more efficient performance. Now almost all people must have switched from being manually switched to computers, nowadays performance is demanded to be faster in solving a problem. Correspondence is a problem that is often handled by computer administrators in order to become faster, the making of letters or reports at the village level government should be using a computer. But in reality, there are still many village officials who cannot yet use computers, especially older employee. Even though in making letters or reports, village administrators are required to work faster. By referring to these problems, at this time service will be conducted a training aimed at village officials about their understanding of information technology, especially the ability of village officials to understand the making of letters or reports using Microsoft Office 2007. Microsoft Word 2007 and Microsoft Excel 2007, this programs is often used when making reports. In the future it is expected that all village administrators can understand the use of this application correctly and precisely.
\end{abstract}

Keywords—: Microsoft Office 2007; Correspondence; Village Administrator.

\section{PENDAHULUAN}

Teknologi Informasi telah berkembang pesat di Indonesia. Hampir semua permasalahan dapat ditangani oleh komputer. Untuk itu setiap lapisan masyarakat harus siap dan mampu mengikuti seiring berkembangnya teknologi. Di Era 90'an, mesin ketik masih menjadi andalan sebagai alat bantu dalam menyusun laporan ataupun membuat surat-surat penting. Setelah berkembangnya teknologi informasi, para pengguna mesin ketik berpindah ke komputer. Karena kinerjanya yang lebih efisien.

Di Era globalisasi, semua masyarakat harus siap beralih dari yang manual berpindah ke komputer. Karena pada era ini, kinerja dituntut lebih cepat dalam menyelesaikan suatu permasalahan. Salah satu contoh permasalahan yang ditangani oleh komputer menjadi lebih cepat adalah pembuatan surat-surat atau laporan di pemerintahan tingkat pedesaan. Pada kenyataannya, masih banyak perangkat desa yang belum dapat menggunakan komputer, terutama perangkat desa yang berusia lanjut. Padahal dalam pembuatan surat-surat atau laporan, perangkat desa dituntut untuk bekerja lebih cepat.

Dengan mengacu permasalahan tersebut, pada pengabdian kali ini akan dilakukan sebuah pelatihan yang ditujukan kepada perangkat desa tentang pemahamannya terhadap teknologi informasi, khususnya kemampuan perangkat desa dalam memahami pembuatan surat-surat atau laporan menggunakan microsoft Office 2007.

\section{MATERI}

Menurut Wikipedia Microsoft Office adalah perangkat lunakpaket aplikasi perkantoran buatan Microsoft dan dirancang untuk dijalankan di bawah sistem operasiMicrosoft Windows dan Mac OS X. Beberapa aplikasi di dalam Microsoft Office yang terkenal adalah Excel, Word, dan PowerPoint.

Sejak dirilis pertama kali, Program Microsoft Office berkembang begitu pesat, dalam proses perkembangannya, para ahli selalu berupaya untuk meningkatkan kualitasnya, adapun proses perkembangan Microsoft sejak awal dirilis yaitu sebagai berikut:

\section{A. Microsoft Office 3.0}

Microsoft Office 3.0 dirilis pada bulan Agustus 1992, berisi Word 2.0, 4.0 Excel, PowerPoint 3.0 dan Mail 3.0. Ini adalah versi pertama Office yang juga dirilis pada CD-ROM. Pada tahun 1993, Microsoft Office Professional dirilis, yang ditambahkan Microsoft Access 1.1.

\section{B. Microsoft Office 4.0, 4.1, 4.2}

Microsoft Office 4.0 dirilis berisi Word 6.0, 4.0 Excel, PowerPoint 3.0 dan Mail. Firman itu disebut Word 6.0 sebagai sudah ada versi Macintosh Word 3, 4 dan 5 (Excel dan PowerPoint sudah bernomor sama dengan versi Macintosh). 
Website : http://dayamas.unmermadiun.ac.id/index.php/dayamas

\section{Microsoft Office 95}

Program Microsoft Office ini dirilis pada bulan Agustus 1995. Sekali lagi, nomor versi yang diubah untuk menciptakan paritas di paket - setiap program yang disebut versi 7.0 kecuali Word. Ia dirancang sebagai sebuah versi 32-bit sepenuhnya cocok dengan Windows 95. Office 95 tersedia dalam dua versi, Office 95 Standard dan Office 95 Professional.

Versi standar terdiri dari Word 7.0, Excel 7.0, 7.0 PowerPoint, dan Schedule + 7.0. Edisi profesional berisi semua item dalam versi standar ditambah Access 7.0. Jika versi profesional dibeli dalam bentuk CD-ROM, juga termasuk Bookshelf.

\section{Microsoft Office 97}

Versi ini dirilis dengan banyak fitur dan pengembangan dibandingkan versi sebelumnya. Pengenalan terhadap command bar, sesuatu hal yang baru dimana menu dan toolbar dibuat lebih mirip dengan visual design-nya. Office 97 juga memiliki fitur Natural Language System dan Sophisticated Grammar Checking. Ini versi yang pertama kalinya menggunakan Office Assistant.

\section{E. Microsoft Office 2000}

Microsoft Office 2000 adalah versi terakhir yang bisa dijalankan di Windows 95, Pada versi ini tidak ada Product Activation. Pada versi ini juga banyak opsi - opsi yang disembunyikan. opsi yang disembunyikan tersebut tentu saja bersifat penting, tetapi kecil penggunaannya oleh orang awam.

Namun Jika ingin digunakan, opsi ini dapat dimunculkan. Salah satunya adalah Macro. opsi-opsi banyak disembunyikan pada office 2000 karena alasan keamanan, yaitu dapat menyebabkan tersebarnya virus macro.

\section{F. Microsoft Office XP (2002)}

Microsoft Office XP ini dirilis bersamaan dengan Windows XP, program Microsoft Office XP ini merupakan upgrade besar dengan berbagai perangkat tambahan dan perubahan atas Office 2000. Office XP memperkenalkan fitur Safe Mode, yang memungkinkan aplikasi seperti Outlook untuk boot jika dinyatakan mungkin gagal.

Safe Mode memungkinkan untuk mendeteksi dan memperbaiki atau memotong sumber masalah, seperti registry yang rusak atau rusak add-in. Tag Smart adalah sebuah teknologi diperkenalkan dengan Office XP. Beberapa tag cerdas beroperasi berdasarkan aktivitas pengguna, seperti membantu dengan kesalahan mengetik. Tag ini pintar yang disertakan dengan produk, dan tidak diprogram.

Dalam Office XP, tag kustom pintar bisa bekerja hanya dalam Word dan Excel. Microsoft Office XP termasuk perintah suara terintegrasi dan kemampuan dikte teks, serta pengenalan tulisan tangan. Office XP adalah versi terakhir untuk mendukung Windows 98, ME dan NT 4.0. Ini adalah versi pertama yang membutuhkan Aktivasi Produk sebagai tindakan anti-pembajakan, yang menarik kontroversi luas.

\section{G. Microsoft Office 2003}

Sesuai namanya, versi ini dirilis pada tahun 2003. Dengan fitur logo baru. Dua aplikasi baru juga ada yaitu, Microsoft InfoPath dan OneNote. Ini versi yang pertama kalinya menggunakan gaya Windows XP beserta Icon-nya.

Outlook 2003 memberikan fungsi yang telah berkembang seperti Kerberos authentication, RPC over HTTP, dan Cached Exchange Mode. Pada versi ini juga ada penyaring junk mail yang telah dikembangkan.

Office 2003 merupakan versi terakhir yang mendukung Windows 2000. Versi ini juga merupakan versi yang paling banyak dipakai di Indonesia terutama untuk Rental dan Warnet dalam kurun waktu terakhir 2009.

\section{H. Microsoft Office 2007}

Program Microsoft Office 2007 dirilis pada tahun 2007. Fitur baru Office 2007 ini termasuk antarmuka pengguna grafis baru yang disebut Fluent User Interface, menggantikan menu dan toolbar yang telah menjadi landasan Office sejak awal dengan toolbar tab, yang dikenal sebagai Pita; baru format file berbasis XML yang disebut Open Office XML, dan masuknya Groove, aplikasi perangkat lunak kolaboratif.

\section{Microsoft Office 2010}

Diselesaikan pada tanggal 15 April 2007, dan dibuat tersedia bagi konsumen pada tanggal 15 Juni 2007. Office 2007 diberi nomor versi 14,0, untuk menghindari nomor versi 13.0 karena takhayul yang berhubungan dengan nomor tiga belas. Fitur utama dari Office 2007 termasuk menu file, alat-alat kolaborasi baru, pita disesuaikan, melihat dilindungi dan panel navigasi.

Microsoft Office 2007 juga dilengkapi dengan logo baru, yang mirip dengan logo 2007, kecuali di emas, dan dengan bentuk yang sedikit dimodifikasi.

\section{J. Microsoft Office 2013 (Versi 15)}

Office 2013 mampu digunakan di perangkat mobile, komputer awan, dan sosial media. Software ini merupakan aplikasi produktivitas terpopuler di dunia dengan miliaran pengguna, Office 2013 ini sepenuhnya dioperasikan dengan layar sentuh, sama halnya dengan OS Microsoft Windows 8.1. 
Website : http://dayamas.unmermadiun.ac.id/index.php/dayamas

\section{K. Microsoft Office 2016 (Versi 16)}

Office 2016 mampu digunakan di perangkat mobile, komputer awan, dan sosial media. Software ini merupakan aplikasi produktivitas terpopuler di dunia dengan miliaran pengguna, Office 2013 ini sepenuhnya dioperasikan dengan layar sentuh, sama halnya dengan OS Microsoft terakhir Windows 10.

\section{III.METODE}

Adapun metode yang akan digunakan dalan pengabdian masyarakat ini adalan menggunakan Pre Test dan Post Test dengan disertai contoh soal yang akan dikerjakan. Pada Pre Test peserta pelatihan akan diberikan soal yang harus dikerjakan lebih dahulu sebelum melaksanakan pelatihan dan akan di nilai hasilnya. Pada Post Test soal yang diberikan akan sama dengan soal pada Pre Test sehingga dapat di ukur peningkatan ketrampilan peserta pelatihan dan akan ditunjukkan oleh grafik.

\section{IV.HASIL DAN PEMBAHASAN}

Pelatihan dilaksanakan dalam waktu satu bulan dengan metode pelatihan dan pendampingan. Untuk pelatihan dilakukan selama 1 minggu (6 pertemuan), pelatihan dilaksanakan di Kantor Desa setempat. Metode pelatihan adalah mengadakan Pre Test di hari pertama untuk mengukur kemampuan individu guna memetakan klasifikasi materi yang akan diberikan, dan di hari terakhir mengadakan Post Test guna mengetahui keberhasilan dari pelatihan tersebut .

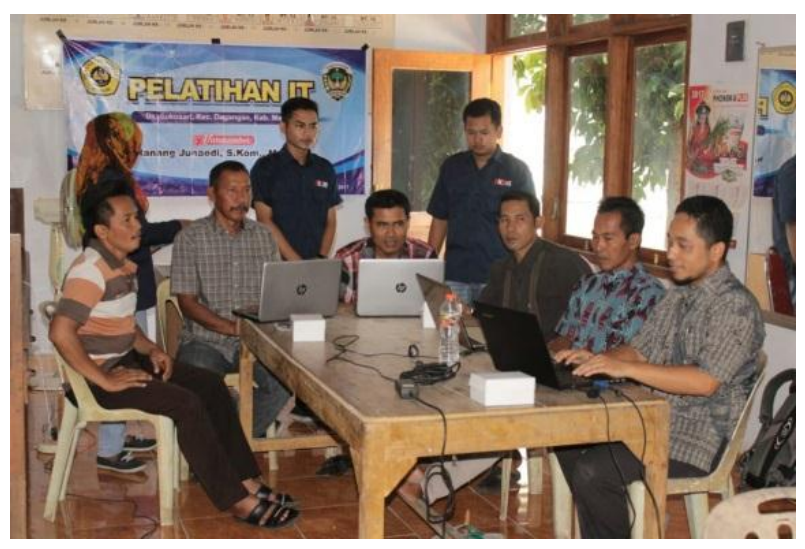

Gambar 1. Proses Pelatihan Microsoft Office 2007

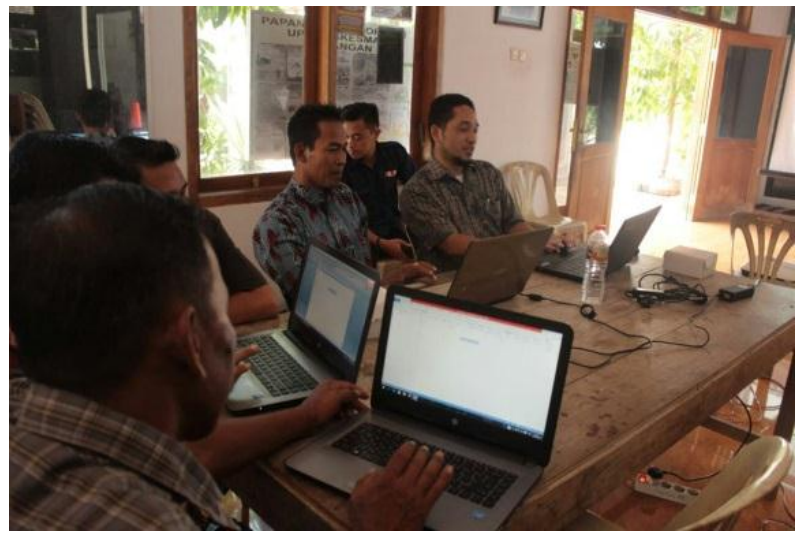

Gambar 2. Proses Pelatihan Microsoft Office 2007

Materi yang diberikan kepada peserta pelatihan adalah meliputi Microsoft Word dan Microsoft Excel. Peserta pelatihan diperkenalkan dengan fitur-fitur dasar dan lanjut dari aplikasi yang digunakan. Dan untuk meningkatkan pemahaman materi, setiap peserta diberikan contoh-contoh latihan kasus dan kemudian untuk diselesaikan. Beberapa fitur yang diperkenalkan pada Microsoft Office adalah Toolbar, Hotkey, Ruler Margin, Formatting, Table, dan membuat kolom Berita. Sedangkan untuk fiturfitur pada Microsoft Excell adalah Formula dan Worksheet. 
Website : http://dayamas.unmermadiun.ac.id/index.php/dayamas

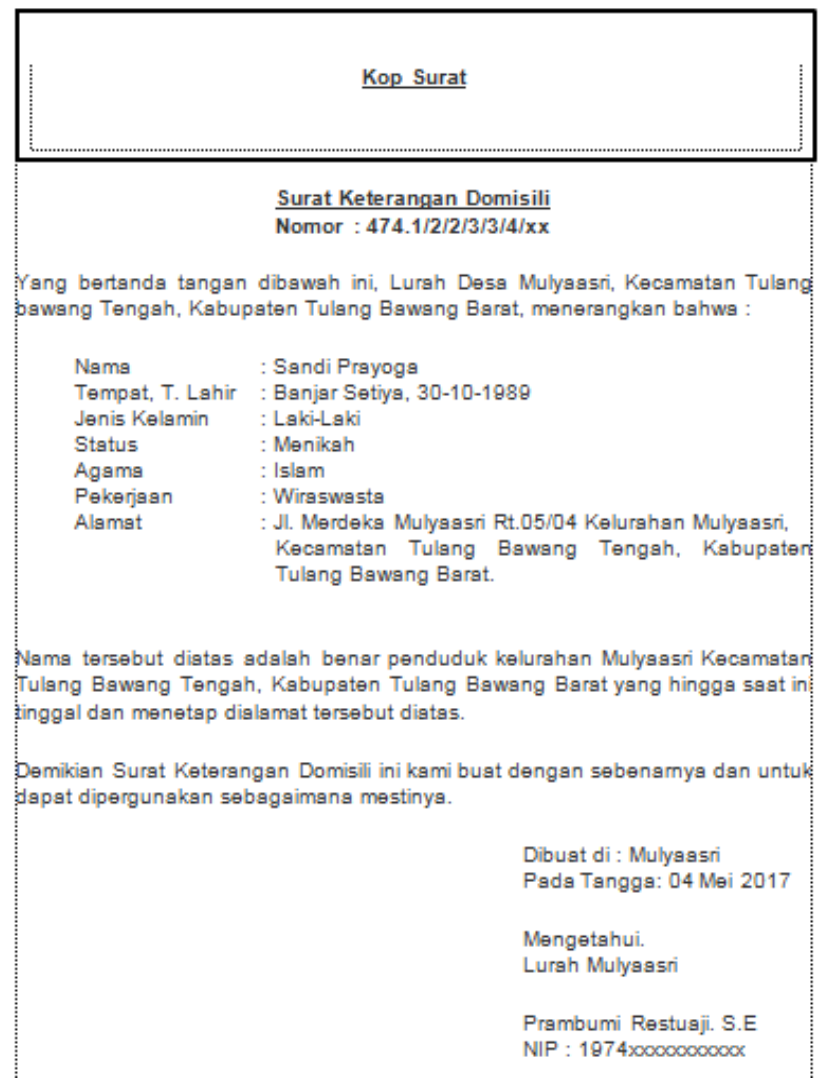

Gambar 3. Soal Latihan Microsoft Word 2007

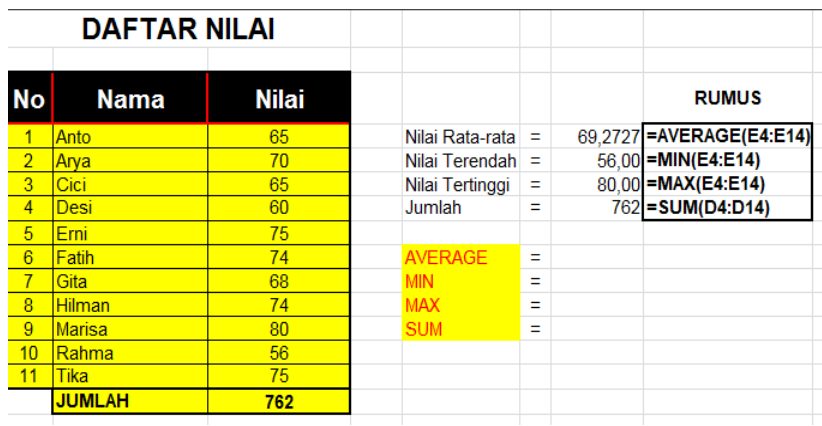

Gambar 4. Soal Latihan Microsoft Excel 2007

Setelah pelatihan selesai maka selanjutnya dilakukan proses pendampingan kepada karyawan dalam melaksanakan tugas sehari-hari yang terkait dengan penggunaan aplikasi Microsoft Office maupun Microsoft Excel. Sehingga dapat memberikan kesempatan pada karyawan untuk bertanya atau berdiskusi terkait dengan permasalahan-permasalahan yang ditemui pada saat melaksanakan tugas.

Untuk mengukur tingkat pemahaman karyawan terhadap materi yang telah diberikan, dilakukan post test yang disampaikan pada saat selesai pelaksanaan pelatihan dan pada akhir masa pendampingan. Dari hasil post test yang telah dilakukan, didapatkan hasil yang ditunjukkan pada Tabel 1 dan Gambar 5.

Tabel 1. Rekapitulasi Data Hasil Pelatihan

\begin{tabular}{|l|l|l|l|l|}
\hline No & Nama & $\begin{array}{l}\text { Pre } \\
\text { Tes }\end{array}$ & $\begin{array}{l}\text { Pos } \\
\text { Test }\end{array}$ & $\begin{array}{l}\text { Peningkatan } \\
\text { Hasil }\end{array}$ \\
\hline 1 & Mustofa & 20 & 70 & 50 \\
\hline 2 & Purwanto A & 25 & 75 & 50 \\
\hline 3 & Aris. A.M & 60 & 90 & 30 \\
\hline 4 & Purwanto B & 40 & 80 & 40 \\
\hline 5 & Tazmun & 30 & 75 & 45 \\
\cline { 2 - 4 } & RERATA & 35 & 78 & \multicolumn{1}{|l}{} \\
\cline { 2 - 3 } &
\end{tabular}


Website : http://dayamas.unmermadiun.ac.id/index.php/dayamas

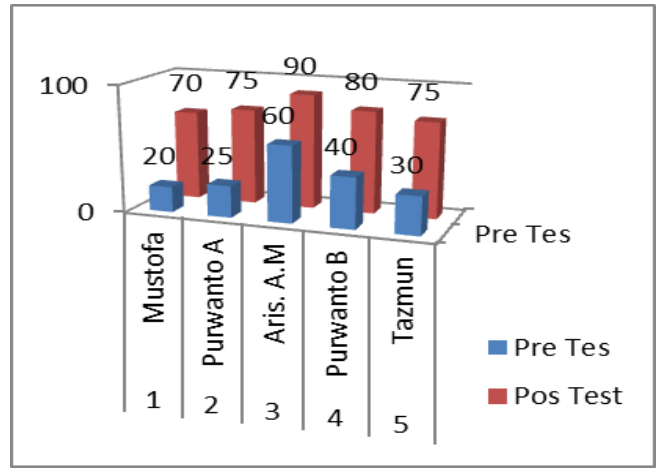

Gambar 5. Hasil Pelatihan

Pada Tabel 1 dan Gambar 5 telah ditunjukkan prosentase hasil pelatihan Microsoft Office 2007 kepada perangkat desa Sukosari, Kecamatan Dagangan, Kabupaten Madiun. Hasil Pre Test Rata-rata hanya 35, sedangkan untuk hasil Post Test sudah meningkat sangat signifikan yaitu 78, adapun peningkatan sangat baik adalah dialami oleh Pegawi No.1 dan No.2 meningkat 50 poin.

\section{KESIMPULAN}

Pelatihan Microsoft Office 2007 untuk perangkat Desa Sukosari, Kecamatan Dagangan, Kabupaten Madiun telah dilaksanakan dan diharapkan memberi manfaat yang lebih bagi administrator desa dalam melaksanakan tugas keseharian, adapun peningkatan ketrampilan ditunjukkan dengan meningkatnya kemampuan perangkat desa dalam mengoperasikan Microsoft Office 2007, sehingga waktu pelayanan menjadi lebih cepat, baik dalam rangka untuk melayani permintaan masyarakat ataupun untuk kepentingan internal desa.

\section{VI.UCAPAN TERIMAKASIH}

Ucapan terima kami sampaikan kepada Bapak Kusno selaku Kepala Desa Sukosari, Kec. Dagangan, Kab. Madiun, beserta jajaran, serta mahasiswa Universitas Merdeka madiun yang ikut membantu dalam menyukseskan pelatihan ini.

\section{DAFTAR PUSTAKA}

https://id.wikipedia.org/wiki/Microsoft_Office

http://office.kampusrahasia.com/pengertian-fungsi-dan-sejarah-microsoft-office/

Sapudin, A. Modul Sejarah Komputer, Microsoft Word 2007, Microsoft Excel 2007

Modul Pelatihan Microsoft Office 2007, Universitas Merdeka Madiun 